\title{
Effects Of Triclosan On The Oyster Parasite, Perkinsus Marinus And Its Host, The Eastern Oyster, Crassostrea Virginica
}

\author{
Fu-Lin E. Chu \\ Virginia Institute of Marine Science \\ Eric D. Lund \\ Virginia Institute of Marine Science \\ Jennifer A. Podbesek \\ Virginia Institute of Marine Science
}

Follow this and additional works at: https://scholarworks.wm.edu/vimsarticles

Part of the Aquaculture and Fisheries Commons

\section{Recommended Citation}

Chu, Fu-Lin E.; Lund, Eric D.; and Podbesek, Jennifer A., Effects Of Triclosan On The Oyster Parasite, Perkinsus Marinus And Its Host, The Eastern Oyster, Crassostrea Virginica (2008). Journal Of Shellfish Research, 27(4), 769-773.

10.2983/0730-8000(2008)27[769:EOTOTO]2.0.CO;2

This Article is brought to you for free and open access by the Virginia Institute of Marine Science at W\&M ScholarWorks. It has been accepted for inclusion in VIMS Articles by an authorized administrator of W\&M ScholarWorks. For more information, please contact scholarworks@wm.edu. 


\title{
EFFECTS OF TRICLOSAN ON THE OYSTER PARASITE, PERKINSUS MARINUS AND ITS HOST, THE EASTERN OYSTER, CRASSOSTREA VIRGINICA
}

\author{
FU-LIN E. CHU,* ERIC D. LUND AND JENNIFER A. PODBESEK \\ Virginia Institute of Marine Science, College of William and Mary, Gloucester Point, Virginia 23062
}

\begin{abstract}
Because temperature plays an important role on progression and transmission of disease caused by Perkinsus marinus in the field, the effects of triclosan on the viability of P. marinus meronts (trophozoites) and oyster hemocytes were tested at a range of environmental relevant temperatures. Additionally, we examined the triclosan effect on reactive oxidative intermediate production (ROI) by oyster hemocytes and tested the efficacy of treating infected oysters with triclosan in eliminating/ reducing $P$. marinus infection in a pilot experiment. When $P$. marinus cultivated at $13{ }^{\circ} \mathrm{C}, 20^{\circ} \mathrm{C}$, and $28^{\circ} \mathrm{C}$ was exposed to triclosan at corresponding temperatures, $2-10 \mu \mathrm{M}$ triclosan killed $10-30 \%$ at $20^{\circ} \mathrm{C}$ and $\geq 40 \%$ at $28^{\circ} \mathrm{C}$, but $\leq 10 \%$ at $13^{\circ} \mathrm{C}$. When exposure of $P$. marinus cultivated at $28^{\circ} \mathrm{C}$ to triclosan at $26^{\circ} \mathrm{C}$, similar mortality was noted as those recorded at $28^{\circ} \mathrm{C}$. Treating hemocytes from oysters maintained at $13^{\circ} \mathrm{C}, 20^{\circ} \mathrm{C}$, or $26^{\circ} \mathrm{C}$ with $2,5,10 \mu \mathrm{M}$ triclosan at corresponding temperatures, killed $2 \%$ to $13 \%$ at $13^{\circ} \mathrm{C}$ and 6 to $16 \%$ at $20^{\circ} \mathrm{C}$. No mortality occurred in hemocytes exposed to $2-10 \mu \mathrm{M}$ triclosan at $26^{\circ} \mathrm{C}$. However, at the highest temperature and triclosan concentration tested $\left(28^{\circ} \mathrm{C}, 10 \mu \mathrm{M}\right.$ triclosan), hemocyte mortality exceed $30 \%$. Exposure of hemocytes to triclosan concentrations of $2-10 \mu \mathrm{M}$ for $4 \mathrm{~h}$ at $4^{\circ} \mathrm{C}$ significantly reduced the ROI production in hemocytes in a dose-dependent response. Treating P. marinus infected oysters with 300 and $600 \mu \mathrm{g}$ triclosan/oyster daily for $8 \mathrm{wk}$, significantly slowed the disease progression.
\end{abstract}

KEY WORDS: Crassostrea virginica, hemocytes, oyster, oyster parasite, Perkinsus marinus, reactive oxidative intermediates, triclosan

\section{INTRODUCTION}

The protozoan parasite Perkinsus marinus, causative agent of Dermo disease, is presently the most prevalent and destructive parasite of the eastern oyster Crassostrea virginica (Gmelin 1791) in midAtlantic water of the United States. It has decimated oyster populations along the Atlantic coast and the Gulf of Mexico for at least $30 \mathrm{y}$. The impact of Dermo disease on the Chesapeake Bay has been particularly devastating in that current oyster populations are now less than $1 \%$ of historic levels. The basis of $P$. marinus's virulence is presently unclear. One unusual aspect of $P$. marinus is that unlike other parasitic protozoans, it is able to synthesize a range of saturated and unsaturated fatty acids, including the essential fatty acid, arachidonic acid (AA, 20:4n-6) (Chu et al. 2002), a precursor for a series of eicosanoids involved in many biochemical and physiological processes. Perkinsus marinus has a nonphotosynthetic plastid in the biflagellate zoospore stage (Perkins 1996).The presence of a plastid in Perkinsus spp. was recently confirmed with molecular and ultrastructural evidence (Teles-Grilo et al. 2007, Stelter et al. 2007). The acyl elongation reaction in the meront (trophozoite) stage of this parasite is catalyzed by a FAE1like ketoacyl-CoA synthase class of condensing enzyme previously only reported in higher plants and algae (Venegas-Caleron et al. 2007). Thus, P. marinus likely uses type II fatty acid synthase pathway for fatty acid synthesis.

Triclosan, a specific inhibitor of type II class of fatty acid synthases, is a widely used and largely unregulated antimicrobicide. It is contained in many daily use household products such as soap, shampoo, toothpaste, and mouthwash. Triclosan inhibits the growth and disease progression of Plasmodium spp. via inhibition of fatty acid synthesis (Surolia \& Surolia 2001). Our previous results revealed that whereas causing minimal effect on oyster hemocyte viability, triclosan not only inhibits

*Corresponding author. E-mail: chu@vims.edu growth and greatly reduces viability of in vitro cultured $P$. marinus meronts, but it also inhibits the parasite's fatty acid synthetic ability (Lund et al. 2005).

Both field and laboratory studies have shown that temperature plays an important role in Dermo disease progression and transmission. Disease prevalence and intensity are positively correlated with temperature (Chu 1996, Chu \& Volety 1997, Burreson \& Ragone-Calvo 1996, Ragone-Calvo et al. 2003). In vitro, $P$. marinus meronts proliferate and develop rapidly to prezoosporangium stage at temperatures of $20^{\circ} \mathrm{C}$ to $30^{\circ} \mathrm{C}$ (Chu \& Greene 1989). Furthermore, temperature significantly affects the lipid metabolism in the parasite. Relevant to rapid disease progression and advancement at high temperature, fatty acid synthesis rates and exogenous lipid incorporation and metabolism in $P$. marinus meronts are positively correlated with temperature (Chu et al. 2003, Lund et al. 2004). The objective of the present study was to test the influence of temperature on effects of triclosan on the viability of $P$. marinus meronts. To address concerns about potential toxic effect on host cells, the effect of triclosan on oyster hemocyte viability at a range of environmentally relevant temperatures and on hemocyte reactive oxidative intermediate production were also examined. Additionally, the efficacy of treating infected oysters with triclosan in eliminating/reducing $P$. marinus infection was tested in a pilot experiment.

\section{MATERIALS AND METHODS}

\section{Experiments}

Effects of Triclosan on Perkinsus marinus Meronts and Oyster Hemocytes at Different Temperatures

Perkinsus marinus meronts were cultivated as previously described (Chu et al. 2002) in medium defined by La Peyre et al. (1993). Medium was prepared with artificial sea water (ASW) and adjusted to an osmolarity of 590 (equivalent to a salinity of 
20, Lund et al. 2004). Medium was then sterilized by $0.2-\mu \mathrm{m}$ filtration and stored at $4^{\circ} \mathrm{C}$ until use. Meronts were inoculated at a concentration of $1 \times 10^{6} / \mathrm{mL}$ and cultivated in $10-\mathrm{mL}$ aliquots of medium in T-10 tissue culture flasks at $13^{\circ} \mathrm{C}, 20^{\circ} \mathrm{C}$, and $28^{\circ} \mathrm{C}$. Meronts at exponential growth phase $(7$ days post inoculation) were harvested to test the effect of triclosan on their viability corresponding to their cultivation temperatures.

To test the effect of triclosan on oyster hemocyte's viability at different temperatures, oyster were maintained in a flowthrough flume with ambient estuarine water (York River, VA, salinity $=16-26 \mathrm{psu}$ ). A few days (5-6 days) after ambient temperature reached $13^{\circ} \mathrm{C}, 20^{\circ} \mathrm{C}$, or $26^{\circ} \mathrm{C}, 8-14$ oysters were selected from the flume randomly for hemolymph sampling. Approximately $1.0 \mathrm{~mL}$ of hemolymph was withdrawn from each oyster. All hemolymph samples were stored individually in microtubes at $4{ }^{\circ} \mathrm{C}$ and examined microscopically for any contamination with bacteria or gametes. If contamination was visible the sample was discarded. Non-contaminated hemolymph samples were pooled and adjusted to a concentration of $2.0-3.0 \times 10^{6}$ cells $/ \mathrm{mL}$ of hemolymph by centrifugation $(1,000$ $\mathrm{rpm}=200 \times \mathrm{g}$ ) for $20 \mathrm{~min} 4^{\circ} \mathrm{C}$ and hemocytes were tested for viability after incubation with different concentrations of triclosan. To test effect of triclosan on oyster hemocytes at the temperature $28^{\circ} \mathrm{C}$, oysters were acclimated to $28^{\circ} \mathrm{C}$ and maintained at the same temperature for up to $2 \mathrm{wk}$ before hemocytes were sampled from oysters for viability assays.

The effects of triclosan on the viability of $P$. marinus meronts and oyster hemocytes were assessed using the MTS/PMS assay. Briefly, $100 \mu \mathrm{L}$ of 7 day old meront culture containing $3.0 \times 10^{6}$ cells/mL medium or $100 \mu \mathrm{L}$ of pooled hemolymph containing 2.0-3.0 $\times 10^{6}$ cells $/ \mathrm{mL}$ of hemolymph was pipetted to each well $(n=8)$ of a 96-well microplate. Two and a half micro liters of triclosan stock solution in EtOH $(0 \mathrm{mM}, 0.08 \mathrm{mM}, 0.2 \mathrm{mM}$, or $0.4 \mathrm{mM})$ were then added to each well $(n=8$ wells per triclosan concentration) to achieve 4 triclosan treatment groups with a final triclosan concentration of $0 \mu \mathrm{M}, 2 \mu \mathrm{M}, 5 \mu \mathrm{M}$, and 10 $\mu \mathrm{M}$ respectively. The final ethanol concentration was $0.5 \%$. The 96-well microplate was incubated at temperatures corresponding to the oyster maintenance $\left(13^{\circ} \mathrm{C}, 20^{\circ} \mathrm{C}, 26^{\circ} \mathrm{C}\right.$, and $\left.28^{\circ} \mathrm{C}\right)$ and P. marinus cultivation $\left(13^{\circ} \mathrm{C}, 20^{\circ} \mathrm{C}\right.$, and $\left.28^{\circ} \mathrm{C}\right)$ temperatures for $24 \mathrm{~h}$ in the dark. Additionally, triclosan effects on meronts cultured at $28^{\circ} \mathrm{C}$ were also tested at $26^{\circ} \mathrm{C}$ and hemocytes from oysters maintained at $26^{\circ} \mathrm{C}$ were also tested at $28^{\circ} \mathrm{C}$. After $24 \mathrm{~h}$ incubation, viability of $P$. marinus meronts and oyster hemocytes were assessed employing the MTS/PMS assay. Briefly, $20 \mu \mathrm{L}$ of the MTS/PMS working solution was added to each well, mixed well and incubated again in the dark for $3 \mathrm{~h}$ at corresponding temperatures $\left(13^{\circ} \mathrm{C}, 20^{\circ} \mathrm{C}, 26^{\circ} \mathrm{C}\right.$, or $\left.28^{\circ} \mathrm{C}\right)$. The absorbance (optical density, OD) of formazan, the reduction product of MTS/PMS, was measured at $450 \mathrm{~nm}$ using a Tecan GENios microplate reader (Maennedorf, Switzerland). Instrument control and data acquisition by MS-Excel was provided by the computer software XFLUOR4 V 4.50 (Tecan, Maennedorf, Switzerland). The percentage of viable cells is expressed as the percentage of the OD measured for the control.

The MTS/PMS assay assesses cell viability and proliferation based on dehydrogenation of oxidizable substrates by dehydrogenase of live cells coupled with the reduction of the tetrazolium dye. It indirectly measures the number of viable cells, because the amount of mitochondrial dehydrogenase present in the samples is directly proportional to the number of viable cells. This assay has been applied to measure viability of other cells, including P. marinus meronts and oyster hemocytes (Dungan \& Hamilton 1995, Volety et al. 1999, Soudant et al. 2005).

The 3,(4,5-dimethylthiazol-2-yl)-5-(3-carboxymethyphenyl)-2-(4-sulfophenyl)-2H-tetrazolium, inner salt (MTS) was obtained from Promega (CellTiter 96 AQ, Cat.\#G1111, Madison, WI, USA) and phenazine methosulfate (PMS) was obtained from Sigma (P9625, St. Louis, MO). MTS and PMS reagents were prepared according to manufacturers' instructions (Promega, CellTiter 96 Aqueous NonRadioactive Cell Proliferation Assay, Technical Bulletin \#169, Promega Corporation, Madison, WI).

\section{Effect of Triclosan on Reactive Oxidative Intermediate (ROI) Production in Oyster Hemocytes}

The ROI production by triclosan treated hemocytes were assessed employing a chemiluminescence assay modified from Bramble and Anderson (1998). Briefly, hemocytes were first treated with different concentrations of triclosan $(0 \mu \mathrm{M}, 2 \mu \mathrm{M}$, $5 \mu \mathrm{M}$, or $10 \mu \mathrm{M}$ triclosan $n=4$ per triclosan concentration) at $4^{\circ} \mathrm{C}$ for $4 \mathrm{~h}$, then the zymosan stimulated ROI production in hemocytes was quantified by luminometry. Uncontaminated pooled hemolymph drawn from 20 oysters maintained in a flowthrough flume with ambient estuarine water (York River, VA, salinity $=16-26 \mathrm{psu}$ ) in January 2006 (temperature $=4-8^{\circ} \mathrm{C}$ ) was centrifuged at $200 \times \mathrm{g}$ for $10 \mathrm{~min}$ at $4^{\circ} \mathrm{C}$. After carefully removing the plasma, hemocytes were gently resuspended in ASW of salinity 20. The resuspended hemocytes were dispensed into 4 Eppendorf tubes and triclosan was added to each tube at concentrations of $0 \mu \mathrm{M}, 2 \mu \mathrm{M}, 5 \mu \mathrm{M}$, or $10 \mu \mathrm{M}$ using ethanol as a carrier. The final ethanol concentration was $0.5 \%$. After incubation at $4^{\circ} \mathrm{C}$ for $4 \mathrm{~h}$ the tubes containing the hemocytes were centrifuged, the supernatant was removed and hemocytes were resuspended in fresh ASW to a concentration of $7 \times 10^{6}$ hemocytes $/ \mathrm{mL}$. One hundred microliters of the hemocyte suspension was added each well of a white flat bottomed 96 well microtiter plate $\left(7 \times 10^{5}\right.$ hemocytes/well, $n=8$ wells/ treatment) along with $70 \mu \mathrm{L}$ luminol working solution. The final luminol concentration was $5 \mu \mathrm{M}$. The plate was then read on a GENios microplate reader in luminometry mode for 5 cycles (integration time $=1,000 \mathrm{~ms}$, gain $=150$, kinetic interval $=$ $142 \mathrm{~s})$ to determine baseline chemiluminescence. Afterward, $20 \mu \mathrm{L}$ of zymosan working solution $(1 \mathrm{mg} / \mathrm{mL})$ was added to 4 wells of each treatment to stimulate an ROI response. The remaining 4 wells from each treatment received $20 \mu \mathrm{L}$ ASW and served as unstimulated controls. The microplate was then returned to the plate reader and chemiluminescence was recorded in kinetics mode for an additional 20 cycles (45 min).

\section{Effects of Triclosan on Dermo Disease Progression in Infected Oysters}

Triclosan is a relatively hydrophobic molecule that has low solubility in sea water. Thus direct addition of triclosan to seawater containing oysters may be an inefficient way to deliver the drug. An experiment was designed to test whether algal feed could be used as a delivery device for the drug by adding triclosan dissolved in ethanol to algal feed used to maintain oysters in closed circulation systems. Concentrated algae (Instant Algae Shellfish diet 1800, Reed Mariculture, Campbell, CA) were used for delivering triclosan to the oysters. Triclosan was dissolved in $\mathrm{EtOH}$ then added to algae $(0.1 \% \mathrm{EtOH}(\mathrm{v} / \mathrm{w})$ 
in all treatment feeds) and stirred at room temperature $\left(20^{\circ} \mathrm{C}\right)$ overnight. The incorporation of triclosan into algae was determined by gas chromatography equipped with a flame ionization detector (GC/FID). Triclosan incorporation efficiency was determined to be $>85 \%$. Three concentrations of triclosan in algae, were fed to Perkinsus-infected oysters (Crassostrea virginica, DEBBIE strain, shell length $=40-70 \mathrm{~mm}$ ). The experimental oysters had been previously maintained in the York River (VA) for more than a year before the start of the experiment in July 2005. Oysters were maintained in $1 \mu \mathrm{m}-$ filtered $20^{\circ} \mathrm{C}$ York River water (YRW) at a density of 20 individuals per $40 \mathrm{~L}$ tank with three replicate tanks per treatment. Water was changed three times per week and oysters were fed $0.2 \mathrm{~g}$ algae per individual daily. Oysters were treated with 0 , 150,300 , or $600 \mu \mathrm{g}$ triclosan per oyster daily by feeding them a combination of triclosan-sorbed algae and nonsorbed algae (a total of $0.2 \mathrm{~g}$ per oyster). Fifteen oysters were sampled prior to the start of the experiment to determine initial $P$. marinus infection levels. After 8 wk 10 oysters from each replicate tank were sampled (30 per treatment group) for determination of $P$. marinus body burden (\# of parasite cells per $g$ of wet oyster tissue weight [g ww], Mean $\pm \mathrm{SE}, n=30$ ) and condition index. To test whether long term triclosan exposure causes death in oysters, triclosan exposure was extended an additional $5 \mathrm{wk}$.

\section{Statistical Analysis}

Analysis of Variance (ANOVA) was conducted on all data to determine differences among treatments. When results were significant $(P<0.05)$, Tukey's test was used to determine significant differences between each sampling point.

\section{RESULTS}

\section{Effects of Triclosan on Perkinsus marinus Meronts and Oyster} Hemocytes: A Comparison at Different Temperatures

Temperature significantly affected the effect of triclosan on the viability of Perkinsus marinus meronts. Perkinsus marinus meront cells were more susceptible to the effect of triclosan at higher temperatures (Table 1). A concentration of $2-10 \mu \mathrm{M}$ triclosan $(0.6,1.5$, and $2.9 \mu \mathrm{g} / \mathrm{mL})$ effectively killed $10 \%$ to $30 \%$ of meronts at $20^{\circ} \mathrm{C}$, and up to $40 \%$ at $26^{\circ} \mathrm{C}$ and $28^{\circ} \mathrm{C}$ (Table 1 ). But, $P$. marinus has a better triclosan tolerance at $13^{\circ} \mathrm{C}$ : viability was reduced only slightly ( $4 \%$ to $10 \%$ ), when $P$. marinus meronts were exposed to $2-10 \mu \mathrm{M}$ triclosan at this temperature (Table 1).

TABLE 1.

Effect of triclosan on the viability of Perkinsus marinus meronts at $13^{\circ} \mathrm{C}, 20^{\circ} \mathrm{C}, 26^{\circ} \mathrm{C}$ and $28^{\circ} \mathrm{C}$. Viability (Mean $\pm \mathrm{SD}, n=8$ ) of triclosan treated $P$. marinus meronts is expressed as the \% of the control (P.marinus meronts incubated with $0 \mu \mathrm{M}$ triclosan).

Letters denote significant differences at the $P<0.05$ level.

\begin{tabular}{|c|c|c|c|c|}
\hline \multicolumn{5}{|c|}{ Viability } \\
\hline Triclosan & $\begin{array}{c}13^{\circ} \mathrm{C} \\
\text { P. marinus }\end{array}$ & $\begin{array}{c}20^{\circ} \mathrm{C} \\
\text { P. marinus }\end{array}$ & $\begin{array}{c}26^{\circ} \mathrm{C} \\
\text { P. marinus }\end{array}$ & $\begin{array}{c}28^{\circ} \mathrm{C} \\
\text { P. marinus }\end{array}$ \\
\hline $0 \mu \mathrm{M}$ & $100^{\mathrm{a}}$ & $100^{\mathrm{a}}$ & $100^{\mathrm{a}}$ & $100^{\mathrm{a}}$ \\
\hline $2 \mu \mathrm{M}$ & $96.1 \pm 13.0^{\mathrm{ab}}$ & $89.5 \pm 5.2^{\mathrm{b}}$ & $54.2 \pm 4.6^{\mathrm{b}}$ & $55.5 \pm 5.2^{\mathrm{b}}$ \\
\hline $5 \mu \mathrm{M}$ & $90.5 \pm 8.5^{\mathrm{b}}$ & $80.5 \pm 6.5^{\mathrm{c}}$ & $54.5 \pm 4.6^{\mathrm{b}}$ & $56.9 \pm 5.4^{\mathrm{b}}$ \\
\hline $10 \mu \mathrm{M}$ & $90.3 \pm 10.7^{\mathrm{b}}$ & $69.7 \pm 4.9^{\mathrm{d}}$ & $62.9 \pm 8.6^{\mathrm{b}}$ & $60.8 \pm 4.6^{\mathrm{b}}$ \\
\hline
\end{tabular}

The effect of triclosan on hemocyte viability did not change much with temperature (Table 2). Exposure of oyster hemocytes to 2, 5, or $10 \mu \mathrm{M}$ triclosan at 13 , and $20^{\circ} \mathrm{C}$ resulted in mortality of $2 \%$ to $16 \%$. No mortality occurred in hemocytes exposed to $2-10 \mu \mathrm{M}$ triclosan at $26^{\circ} \mathrm{C}$. Only at the highest temperature and triclosan concentration tested $\left(28^{\circ} \mathrm{C}, 10 \mu \mathrm{M}\right.$ triclosan $)$ did hemocyte mortality exceed $30 \%$ (Table 2). Similarly, mortality of $>30 \%$ occurred when hemocytes from oysters maintained at $26^{\circ} \mathrm{C}$ were exposed to $10 \mu \mathrm{M}$ triclosan at $28^{\circ} \mathrm{C}$ (data not shown).

\section{Effect of Triclosan on Reactive Oxidative Intermediate (ROI) Production in Oyster Hemocytes}

In all treatments hemocytes stimulated with zymosan produced a significant chemiluminescence response (ROI burst) relative to the unstimulated controls (Fig. 1). A dose-dependent response of chemiluminescence production with significant treatment effect was noted when hemocytes were exposed to $0 \mu \mathrm{M}, 2 \mu \mathrm{M}, 5 \mu \mathrm{M}$, or $10 \mu \mathrm{M}$ triclosan at $4^{\circ} \mathrm{C}$, a temperature similar to the oyster maintenance temperature when the assays were conducted. These results suggest that triclosan exposure significantly reduced the ROI production as measured by chemiluminescence assay.

\section{Effects of Triclosan on Dermo Disease Progression in Infected Oysters}

At the start of the experiment, the initial parasite burden in infected oysters was $34,000 \pm 44,000$ cells $/ g$ ww $(n=15$, Mean \pm $\mathrm{SD})$. Although all of the triclosan treatment groups exhibited higher body burdens relative to the initial sampling, treating $P$. marinus infected oysters with triclosan concentrations of 300 and $600 \mu \mathrm{g} /$ oyster daily for $8 \mathrm{wk}$, significantly slowed down the disease progression (Fig. 2) as indicated by lower parasite burdens in the groups treated with 300 and $600 \mu \mathrm{g}$ triclosan/ oyster/day.

The control treatment had the highest body burden $(252,513 \pm$ $120,857$ cells $/ \mathrm{g} \mathrm{ww})$ of all treatments and the 300- and $600-\mu \mathrm{g}$ treatments $(169,657 \pm 63,825$ and $213,785 \pm 71,551$ cells $/ g$ ww $)$ had significantly lower body burdens than the control. The 150 $\mu \mathrm{g} /$ day treatment body burdens $(229,667 \pm 53,957$ cells $/ \mathrm{g} w w)$ were intermediate in intensity between the control and the higher dosage treatments, but not significantly different from either. Oyster mortality was low when triclosan exposure was extended to $14 \mathrm{wk}$ of exposure. Mortalities were 3.3\%, 3.3\%, $1.6 \%$, and $8.3 \%$ for the control, $150 \mu \mathrm{g}, 300 \mu \mathrm{g}$, and $600 \mu \mathrm{g}$

TABLE 2.

Effect of triclosan on the viability of oyster hemocytes at 13, 20, 26 and $28^{\circ} \mathrm{C}$. Viability (Mean $\pm \mathrm{SD}, n=8$ ) of triclosan treated hemocytes is expressed as the \% of the control (hemocytes incubated with $0 \mu M$ triclosan). Letters denote significant differences at the $\boldsymbol{P}<0.05$ level.

\begin{tabular}{ccccc}
\hline \hline \multicolumn{5}{c}{ Viability } \\
\hline Triclosan & $\begin{array}{c}\mathbf{1 3}^{\circ} \mathbf{C} \\
\text { Hemocytes }\end{array}$ & $\begin{array}{c}\mathbf{2 0}^{\circ} \mathbf{C} \\
\text { Hemocytes }\end{array}$ & $\begin{array}{c}\mathbf{2 6}^{\circ} \mathbf{C} \\
\text { Hemocytes }\end{array}$ & $\begin{array}{c}\mathbf{2 8}^{\circ} \mathbf{C} \\
\text { Hemocytes }\end{array}$ \\
\hline $0 \mu \mathrm{M}$ & $100^{\mathrm{a}}$ & $100^{\mathrm{a}}$ & $100^{\mathrm{a}}$ & $100^{\mathrm{a}}$ \\
$2 \mu \mathrm{M}$ & $97.8 \pm 6.4^{\mathrm{a}}$ & $93.7 \pm 4.9^{\mathrm{ab}}$ & $100^{\mathrm{a}}$ & $100^{\mathrm{a}}$ \\
$5 \mu \mathrm{M}$ & $89.5 \pm 5.2^{\mathrm{b}}$ & $88.6 \pm 2.2^{\mathrm{bc}}$ & $100^{\mathrm{a}}$ & $100^{\mathrm{a}}$ \\
$10 \mu \mathrm{M}$ & $86.9 \pm 4.8^{\mathrm{b}}$ & $84.1 \pm 10.4^{\mathrm{c}}$ & $100^{\mathrm{a}}$ & $63.0 \pm 20^{\mathrm{b}}$ \\
\hline
\end{tabular}




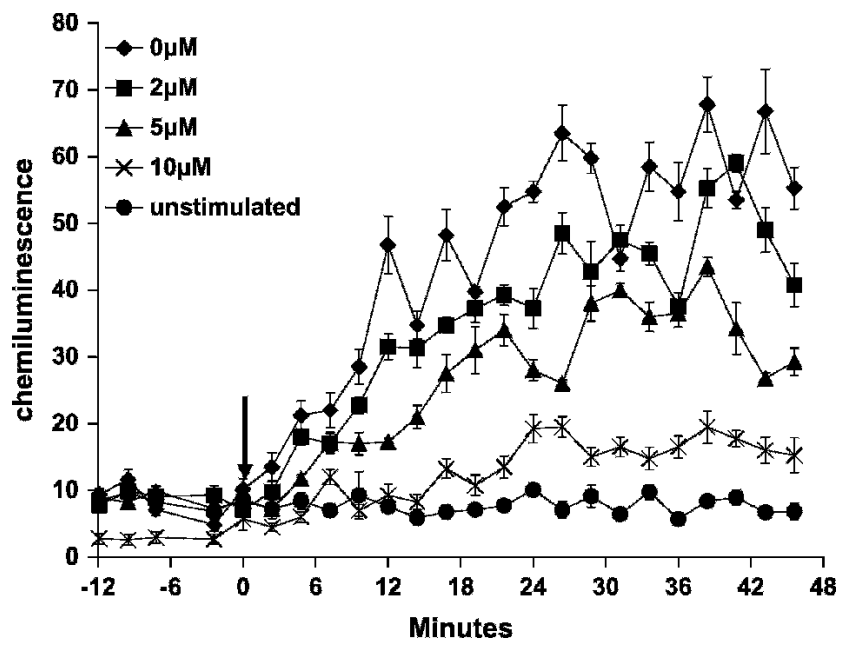

Figure 1. Reactive oxidative intermediate (ROI) production (chemiluminescences) in unstimulated and zymosan stimulated oyster hemocytes after $4 \mathrm{~h}$ incubation with triclosan at $4^{\circ} \mathrm{C}(n=6)$. The arrow indicates the time when zymosan was added to the hemocytes to stimulate ROI.

treatments, respectively. No significant change in oyster condition index caused by triclosan exposure was observed. Condition indices for all treatments were not significantly different from one another at the $P<0.05$ level.

\section{DISCUSSION}

Results obtained from the present study are consistent with our previous findings (Lund et al. 2005). Triclosan greatly reduces cell viability of in vitro cultured Perkinsus marinus, but it has much less effect on oyster hemocyte viability. These effects are consistent with a mode of action in which triclosan acts as an inhibitor of type II fatty acid synthases, which has been found in bacteria and several Apicomplexan protists. Triclosan inhibits the growth and disease progression of Plasmodium spp. via inhibition of fatty acid synthesis (Surolia \& Surolia 2001). Triclosan killed procyclic and bloodstream forms of Trypanosoma brucei in culture and inhibited its fatty acid remodeling and

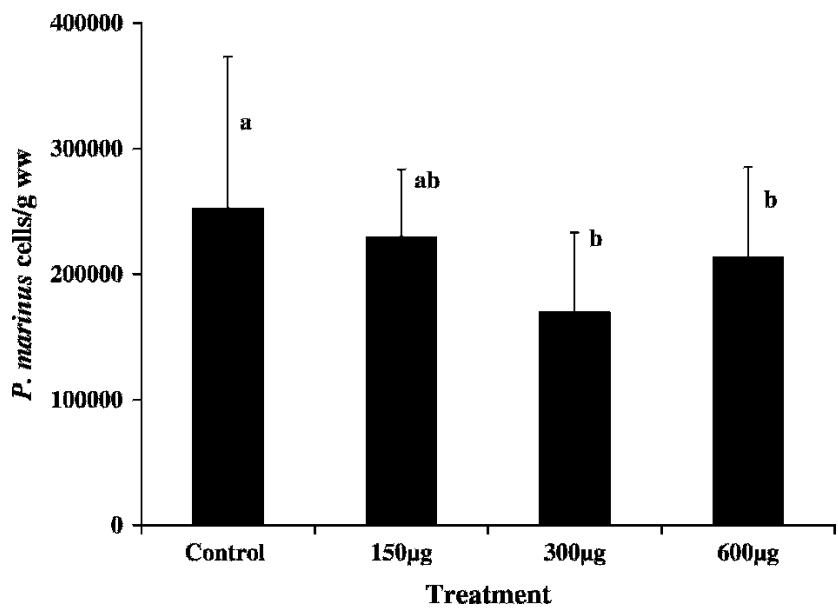

Figure 2. Perkinsus marinus body burdens of oysters treated with 0,150 , 300 , and $600 \mu \mathrm{g}$ triclosan/day for $8 \mathrm{wk}$. Values are mean $\pm \mathrm{SE}(n=30)$. Different letters denote significant differences at the $\boldsymbol{P}<0.05$ level. myristate exchange pathway (Paul et al. 2004). The in vitro tested concentrations are 1,000 times lower than the level allowed by FDA in daily use hygiene products such as toothpaste and mouthwash $(3 \mathrm{~g} / \mathrm{L}$ versus $2.9 \mathrm{mg} / \mathrm{L}$ for $10 \mu \mathrm{M})$.

Temperature plays an important role in regulating the interaction of Perkinsus marinus and its host, the eastern oyster, Crassostrea virginica (Andrews 1988, Chu \& La Peyre 1993, Burreson \& Ragone-Calvo 1996, Ragone-Calvo et al. 2003). Disease progression and transmission in the field is positively correlated with temperature (Andrews 1988, Burreson \& Ragone-Calvo 1996). High temperatures favor P. marinus development at in vitro conditions (Chu \& Greene 1989) and a laboratory study has shown that disease prevalence and intensity are positively correlated with experimental temperatures (Chu \& La Peyre 1993). Previously, we tested the effect of temperature on the uptake and metabolism of fluorescent lipid analogs and fatty acid synthesis by $P$. marinus meronts (Chu et al. 2003). It was found that: (1) low metabolism and bioconversion of incorporated fluorescent lipid analogs at low temperatures $\left(10^{\circ} \mathrm{C}<18^{\circ} \mathrm{C}<28^{\circ} \mathrm{C}\right)$; (2) fatty acid synthesis rate decreases with decreasing cultivation temperatures $\left(10^{\circ} \mathrm{C}<\right.$ $18^{\circ} \mathrm{C}<28^{\circ} \mathrm{C}$ ), and (3) the synthesis rate for the eicosanoid precursor, arachidonic acid, is suppressed at $10^{\circ} \mathrm{C}$ (Lund et al. 2004). Surprisingly, results of the present study showed that $P$. marinus meront cells were more susceptible to the effect of triclosan at higher temperatures, but had a better triclosan tolerance at $13^{\circ} \mathrm{C}$. It is not known whether it is because of temperature effects on the solubility of this hydrophobic drug. Triclosan has a solubility in water of $10 \mathrm{mg} / \mathrm{L}$ at $20^{\circ} \mathrm{C}$ (Yalkowsky \& He 2003), over 3-fold higher than the highest triclosan concentration tested in this study $(10 \mu \mathrm{M}=2.9 \mathrm{mg} / \mathrm{L})$. The profound effect of triclosan at high temperature on $P$. marinus may be good for infected oysters.

Triclosan exposure at concentrations $2-10 \mu \mathrm{M}$ caused much higher mortality in $P$. marinus meronts than in hemocytes at $20^{\circ} \mathrm{C}, 26^{\circ} \mathrm{C}$, and $28^{\circ} \mathrm{C}$. The high mortality recorded in hemocytes derived from oysters maintained at $28^{\circ} \mathrm{C}$ and exposed to $10 \mu \mathrm{M}$ triclosan is believed to be caused by a synergistic effect of high triclosan concentration and temperature stress, because hemocytes tested at $26^{\circ} \mathrm{C}$ and the same triclosan concentration $(10 \mu \mathrm{M})$ did not exhibit any mortality. It has been reported that phagocytic activity of oyster hemocytes is reduced at temperatures greater than $25^{\circ} \mathrm{C}$ (Chu \& LaPeyre 1993). Oysters lack a specific immune response, but possess various humoral and cellular factors important in defense against pathogenic microbes. Cell-mediated defense mechanisms are mainly carried out by hemocytes in oysters (Chu 2000). Hemocytes are considered to be the primary cellular effectors because of their ability to recognize, phagocytose and destroy a spectrum of microbes including bacteria, yeast and Perkinsus marinus meronts (La Peyre et al. 1995, Chu 2000). The synergistic effects of lysosomal enzymes and cytotoxic oxygen metabolites (e.g., $\mathrm{O}_{2}^{-}, \mathrm{H}_{2} \mathrm{O}_{2},{ }^{1} \mathrm{O}_{2}$, NO) produced from respiration burst during phagocytosis are critical for the killing of the phagocytosed or encapsulated pathogens (see review: Chu 2000). Significant reduction of ROI production in triclosan treated oyster hemocytes at in vitro conditions suggests an effect of triclosan on oyster physiological functions including immune defense system. However, in the present study the effect of triclosan on ROI response was tested only at a temperature $\left(4^{\circ} \mathrm{C}\right)$ similar to the oyster maintenance temperature at the time when 
hemolymph was sampled. Further studies are needed to test the impact of triclosan on ROI production at a range of temperatures similar to the hemocyte viability studies in the present study to determine whether temperatures influence the triclosan effect on ROI production. Moreover, it would be interesting to pursue in the future a study that follows the ROI response along with Dermo progression at a range of temperatures.

Results of the present study suggest that treatment with triclosan can reduce Perkinsus marinus infection intensities in infected oysters relative to untreated oysters. The $300 \mu \mathrm{g}$ triclosan/day treatment appears to exhibit the most desirable responses of the treatments tested: lowest $P$. marinus infection level and lowest mortality. The in vivo tested concentrations, 150,300 , and $600 \mu \mathrm{g}$ per day $(0.52,1.04$, and $2.07 \mu$ mole respectively) is 10-20 times lower than the allowed level by FDA in daily use of toothpaste $(7.5 \mathrm{mg} /$ dose $)$. However, further experiments are needed to confirm these results and modifica- tions to the protocol will probably be required to actually reduce infection intensities, rather than just reduce the rate of replication under conditions conducive to parasite proliferation. Furthermore, it is necessary to determine if there is any triclosan bioaccumulation in oysters after feeding with triclosan sorbed algae. Therefore, although our results suggest that this drug may be useful in treating infected oysters, further toxicology studies utilizing infected and uninfected oysters will be required to ultimately determine the utility of using triclosan to treat Dermo infections in hatchery and research environs.

\section{ACKNOWLEDGMENTS}

This study is funded by a NSF grant (MCB-0131108) and a grant from ODRP, Sea Grant, NOAA (Grant \#V710720). Contribution no. 2944 by the Virginia Institute of Marine Science, College of William and Mary.

\section{LITERATURE CITED}

Andrews, J. D. 1988. Epizootiology of the disease caused by the oyster pathogen Perkinsus marinus and its effects on the oyster industry. Amer. Fish. Soc. Spec. Publ. 18:47-63.

Bramble, L. H. \& R. S. Anderson. 1998. A comparison of the chemiluminescent response of Crassostrea virginica and Morone saxatilis phagocytes to zymosan and viable Listonella anguillarum. Dev. Comp. Immunol. 22:55-61.

Burreson, E. M. \& L. M. Ragone-Calvo. 1996. Epizootiology of Perkinsus marinus disease of oysters in Chesapeake Bay, with emphasis on data since 1985. J. Shellfish Res. 15:17-34.

Chu, F.-L. E. 1996. Laboratory investigations of susceptibility, infectivity and transmission of Perkinsus marinus in oysters. J. Shellfish Res. 15:57-66.

Chu, F.-L. E. 2000. Defense mechanisms of marine bilvalves. In: M. Fingerman, \& R. Nagabhushanam, editors. Recent advances in marine biotechnology; Vol 5, Immunology and pathology. Enfield: Science Publishers Inc. pp. 1-43.

Chu, F.-L. E. \& K. H. Greene. 1989. Effect of temperature and salinity on in vitro culture of the oyster pathogen, Perkinsus marinus (Apicomplexa: Perkinsea). J. Invert. Pathol. 53:260-268.

Chu, F.-L.E. \& J. LaPeyre. 1993. Perkinsus marinus susceptibility and defense-related activities in eastern oysters Crassostrea virginica: temperature effects. Dis. Aquat. Org. 16:223-234.

Chu, F.-L. E. \& A. K. Volety. 1997. Disease processes of the parasite Perkinsus marinus in eastern oyster Crassostrea virginica: minimum dose for infection initiation, and interaction of temperature, salinity and infective cell dose. Dis. Aquat. Org. 28:61-68.

Chu, F.-L. E., E. Lund, P. Soudant \& E. Harvey. 2002. De novo arachidonic acid synthesis in Perkinsus marinus, a protozoan parasite of the eastern oyster Crassostrea virginica. Mol. Biochem. Parasitol. 119:179-190.

Chu, F.-L. E., P. Soudant \& E. D. Lund. 2003. Perkinsus marinus, a protozoan parasite of the Eastern oyster (Crassostrea virginica): effects of temperature on the uptake and metabolism of fluorescent lipid analogs and lipase activities. Exp. Parasitol. 105:121-130.

Dungan, C. F. \& R. M. Hamilton. 1995. Use of a tetrazolium-based cell proliferation assay to measure effects of in vitro conditions on Perkinsus marinus (Apicomplexa) proliferation. J. Eukaryot. Microbiol. 42:379-388.

La Peyre, J. F., M. Faisal \& E. M. Burreson. 1993. In vitro propagation of the protozoan Perkinsus marinus, a pathogen of the eastern oyster, Crassostrea virginica. J. Eukaryot. Microbiol. 40:304-310.

La Peyre, J. F., F.-L. E. Chu \& W. K. Vogelbein. 1995. In vitro interaction of Perkinsus marinus merozoites with Eastern and Pacific oyster hemocytes. Dev. Comp. Immunol. 19:291-304.
Lund, E. D., F.-L. E. Chu \& E. Harvey. 2004. In vitro effects of temperature and salinity on fatty acid synthesis in the oyster protozoan parasite Perkinsus marinus. J. Exp. Mar. Biol. Ecol. 307:111-126.

Lund, E. D., P. Soudant, F.-L. E. Chu, E. Harvey, S. Bolton \& A. Flowers. 2005. Effects of triclosan on growth, viability and fatty acid synthesis of the oyster protozoan parasite Perkinsus marinus. Dis. Aquat. Org. 67:217-224.

Paul, K. S., C. J. Bacchi \& P. Englund. 2004. Multiple triclosan targets in Trypanosoma brucei. Eukaryot. Cell 3:855-861.

Perkins, F. O. 1996. The structure of Perkinsus marinus (Mackin, Owen and Collier,1950) Levine, 1978 with comments on taxonomy and phylogeny of Perkinsus spp. J. Shellfish Res. 15:67-87.

Ragone-Calvo, L. M., C. F. Dungan, B. S. Roberson \& E. M. Burreson. 2003. Systematic evaluation of factors controlling Perkinsus marinus transmission dynamics in lower Chesapeake Bay. Dis. Aquat. Org 56:75-86.

Soudant, P., F.-L. E. Chu \& E. D. Lund. 2005. Assessment of the cell viability of cultured Perkinsus marinus (Perkinsea), a parasitic protozoan of the eastern oyster, Crassostrea virginica, using SYBRgreenpropidium iodide double staining and flow cytometry. J. Eukaryot. Microbiol. 52:492-499.

Stelter, K., N. M. El-Sayed \& F. Seeber. 2007. The expression of a planttype ferredoxin redox system provides molecular evidence for a plastid in the early dinoflagellate Perkinsus marinus. Protist 158: $119-130$.

Surolia, N. \& A. Surolia. 2001. Triclosan offers protection against blood stages of malaria by inhibiting enoyl-ACP reductase of Plasmodium falciparum. Nat. Med. 7:167-172.

Teles-Grilo, M. L., J. Tato-Costa, S. M. Duarte, A. Maia, G. Casal \& C. Azevedo. 2007. Is there a plastid in Perkinsus atlanticus (Phylum Perkinsozoa)? Eur. J. Protistol. 43:163-167.

Venegas-Caleron, M., F. Beaudoin, O. Sayanova \& J. A. Napier. 2007. Co-transcribed genes for long chain polyunsaturated fatty acid biosynthesis in the protozoon Perkinsus marinus include a plantlike FAE1 3-ketoacyl coenzyme A synthase. J. Biol. Chem. 282:2996-3003.

Volety, A. K., L. M. Oliver, F. J. Genthner \& W. S. Fisher. 1999. A rapid tetrazolium dye reduction assay to assess the bactericidal activity of oyster (Crassostrea virginica) hemocytes against Vibrio parahaemolyticus. Aquaculture 172:205-222.

Yalkowsky, S. H. \& Y. He. 2003. Handbook of aqueous solubility data. Boca Raton, London, New York, Washington DC: C.R.C. Press. $1,496 \mathrm{pp}$. 